\title{
No Contest: Corporate Lawyers and the Perversion of Justice in America
}

Douglas M. Branson

Follow this and additional works at: https://scholarlycommons.law.case.edu/caselrev

Part of the Law Commons

\section{Recommended Citation}

Douglas M. Branson, No Contest: Corporate Lawyers and the Perversion of Justice in America, 48 Case W. Rsrv. L. Rev. 459 (1998)

Available at: https://scholarlycommons.law.case.edu/caselrev/vol48/iss2/10

This Book Review is brought to you for free and open access by the Student Journals at Case Western Reserve University School of Law Scholarly Commons. It has been accepted for inclusion in Case Western Reserve Law Review by an authorized administrator of Case Western Reserve University School of Law Scholarly Commons. 


\title{
BOOK REVIEW
}

\author{
NO CONTEST: CORPORATE LAWYERS AND THE \\ PERVERSION OF JUSTICE IN AMERICA \\ BY RALPH NÁDER \& WESLEY J. SMITH \\ NEW YORK: RANDOM HOUSE \\ PP. XXVIII - 427. $\$ 25.95$
}

Reviewed by Douglas M. Branson ${ }^{\dagger}$

This is not a book about corporate lawyers, at least as lawyers use that term. This is a book about lawyers corporations hire-trial lawyers mainly-and their use of litigation tactics that subvert justice. ${ }^{1}$

No Contest is a typical muckraking Nader book. That is to say, as with previous books by Nader and co-authors, ${ }^{2}$ Messrs. Nader and Smith espouse a number of one sided and alarmist views on many subjects. Frequently, their prose waxes histrionic: Corporate lawyers "are now on missions of taking away, generically, the rights and remedies of people ... so they do not have a

W. Edward Sell Professor of Law, University of Pittsburgh.

1. The only exception may be the passage describing the machinations of the Skadden Arps law firm leading to replacement of Justice Andrew Moore on the Delaware Supreme Court. See RALPH NADER \& WeSLEY J. SMITH, No CONIEST: CORPORATE LAWYERS AND THE PERVERSION OF JUSTICE IN AMERICA 207-11 (1990) ("Seeking Justice in Delaware").

2 See, e.g., Ralph Nader \& Wesley J. SMith, Collision COURSE: The Truth ABOUt AIRLINE SAFETY (1993); RALPH NADER ET AL., TAMING tHE GIANT CORPORATION (1976); RALPH NADER, UNSAFE AT ANY SPEED (1965). 
chance to plead for justice." In Nader's view, he and Smith have successfully described "[t]he degrading role of the corporate attorney as a clever hired hand supinely following orders so long as the big checks keep flowing.". Come on! ${ }^{5}$

The book also contains outdated and recycled material, inserted to bulk up the volume. The two authors also describe as failures of the legal system what are in reality imperfections that judges and legislators have attempted to put right, albeit often on a belated basis.

Those faults delineated, to be amplified later, No Contest does describe the "winning is everything" mentality that today infects litigation. The view of many lawyers that the end justifies the means leads to secret settlements and confidentiality agreements designed to delay or suppress justice in subsequent cases involving, for example, the same defective product; discovery abuse and stonewalling for no purpose other than to deplete plaintiffs' resources and enlarge the defense firm's billable time; spoliation (destruction or defacement) of evidence in the name of zealous advocacy; or bullying tactics epitomized by the Strategic Lawsuits Against Public Participation (SLAPP), designed to deflate or destroy activists who challenge large corporations' agendas. Anyone who does a significant amount of trial work encounters these litigation abuses, but not only in cases in which the defendant is a large corporation. These abuses infect the entire civil justice system. They may be no more than symptomatic of an attitude pandemic in the society of which the civil justice system is a part.

\section{HALF-TRUTHS AND ONE-SIDED VIEWS}

Nader and Smith write a book that condemns the practice which is endemic in a certain segment of the bar-that populated by powerful, large law firm lawyers who attended the nation's elite law schools. Nader and Smith then project that condemnation over the entire profession, or a large portion of it. The very beginning

3. NADER \& SMTTH, supra note 1 , at 359.

4. See id.

s. For other expressions of Nader's and Smith's opinions of corporate attorneys, see also $i d$. at xxi (condemning the "raw mercantilist ethic so prevalent in today's modern corporate law culture"), id. at xxiv (characterizing corporate lawyers as "masterminds of choreographing contests that are, in fact, no contest at all"), or id. at 357 (claiming to have catalogued "the oppressive conduct of many corporate attorneys and their unsavory tactics"). 
of the book recounts the twenty-fifth reunion of the Harvard Law class of 1970. One alumna, a partner in a large law firm, wonders about spending her professional life "making rich people richer."

Nader and Smith base their examination of the nation's system of legal education upon observations gleaned at Harvard, and also at Columbia. They find that at these places "faculty members are often too busy with their moonlighting business consultantships" to engage in advocacy for reform of the civil justice system. ${ }^{7}$ In part fueled by professors' headlong pursuit of lucre, "the law school environment, taken as a whole, [becomes] awash in cynical apathy or commercialism." In United States law schools, then, "the majority of the lights at the end of the law school tunnel are those that flicker from the luxurious office buildings of corporate law practices."

Colorful prose-but not representative of what most lawyers do in corporate law firms, or of the nation's other 170 accredited law schools (or, probably, of Harvard and Columbia). Most lawyers in a business practice are engaged in helping distinctly middle class clients organize the affairs of small and medium size businesses. They advise on minimization of taxes, compliance with labor and employment security laws, occupational health and safety issues, and similar questions. And that is even true of much of the practice in large big-city law firms. The experiences of the Harvard Law class of 1970 are simply not representative of 99.9 percent of the profession. Thus, Nader and Smith never demonstrate that they are even aware of what most "corporate lawyers" do.

Nader and Smith also seem not to have been near a law school-or at least an ordinary mortal one-in many a year. Law graduates and students are fighting to survive the seventh consecutive year of a hiring drought. Large law firms are hiring at onequarter or one-fifth the pace at which they hired in the mid-eighties. Predictions are that the practice of law will never return to the generous staffing levels that characterized it a decade ago. Corporate clients will no longer put up with the billing and staffing practices which characterized that earlier era. Therefore, students are scrambling for jobs.

\footnotetext{
a. Id. at xiii.

7. Id. at 336 (discussing the failure of law schools to provide students with opportunities positively to change legal practice).

8. Id. at 337.

9. Id. at 335 .
} 
Historically, and today, at most "real" law schools, only a small minority of students aspire to a corporate practice. Students are also interested in environmental and land use law, public and private international law, criminal prosecution or defense, alternative dispute resolution, or small firm litigation practice involving large doses of personal injury plaintiff and defense work. A few third year students still harbor an idealistic hope to earn a living litigating the pressing constitutional issues of the day, or doing death row appeals. Furthermore, while students have downscaled their aspirations on a widespread basis, the one aspirational segment that does not seem to have suffered is the idealistic, a significant group of law students who, I would venture to say, outnumber the business practice aspirants.

As for the faculty, on a representative faculty of 30 or so members, only three, four or perhaps five may consult on a regular basis. Moreover, most law schools have seen a pronounced amplification of public law offerings, and for teachers of those offerings, consulting opportunities are rare. In viewing those law faculty who do consult, I have not seen a faculty member exceed the "no more than one day per week" in consulting that prevails everywhere in legal academe. Most do less.

Among other non-representative views are Nader and Smith's failure to acknowledge even awareness that plaintiffs' attorneys, too, engage in some of the practices they condemn. Plaintiffs stonewall in discovery from time to time. ${ }^{10}$ Plaintiffs engage in fishing trips. Plaintiffs have been known to attempt to "conflict out" expert witnesses readily available on an issue."

I do not expect a Nader book to achieve balance. And my personal sympathies lie with plaintiffs and against large corporations and the "Crush-em, Bash-em and Sanction-em" law firms that tend to represent them. Nonetheless, this book would gain im-

10. See, e.g., Cine Forty-Second Street Theatre Corp. v. Allied Artists Pictures Corp., 602 F.2d 1062 (2d Cir. 1979) (for three years plaintiff failed to submit meaningful answers to interrogatories).

11. Under the Federal Rules of Civil Procedure, only upon "a showing of exceptional circumstances" may a defendant obtain the names of, much less use, experts plaintiff has consulted or retained but who will not testify at trial. FED. R. CIV. P. 26(b)(4)(B); see also Kuster v. Harner, 109 F.R.D. 372, 375 (D. Minn. 1986) (ruling that the defendants could not discover list of medical experts who plaintiff consulted, but who would not testify at trial); Puerto Rico Aqueduct \& Sewer Authority v. Clow Corp., 108 F.R.D. 304, 311 (D.P.R. 1985) (ruling that the defendant corporations could not discover the identities of numerous non-testifying experts retained by plaintiff). 
mensely in credibility if from time to time it noted that another side exists.

\section{RECYCLED AND FILLER MATERIAL}

Richard Nixon always returned to his shining moment of redemption, the Checkers speech of 1956 . So does Ralph Nader. At no less than three points, ${ }^{12}$ No Contest recounts episodes in the Chevrolet Corvair pratfall that first brought Ralph Nader into the national limelight. ${ }^{13}$ The authors even devote a few pages to the Ford Pinto litigation of the early 1970 s. $^{14}$ These scandals are decades old. One suspects that Nader and Smith could not find enough current incriminating material to fill a book.

They also bulk up the book by recounting episodes to which the reaction should be "so what?" For example, in "The Case of the Pampered Utility," they seem scandalized that "in the summer of 1988, [Commonwealth] Edison crews had used water from city fire hydrants to cool down overheated electrical equipment."15 Personally, if by doing so Edison averted damage to persons or property, I do not care if Edison employees used city water, or holy water. And I doubt that anyone else would either.

Such filler material simply does not jibe with the introduction's preview of the pages to follow: "This book strives to demonstrate how power lawyers can harm innocent and vulnerable people and undermine the rule of law. What we describe is not rare [then why dig up the Corvair three times?]; it is conduct all too representative of many corporate attorneys."16

\section{EXCESSIVE ALARMISM}

This book catalogues what allegedly are failures of the civil justice system only to reveal in ensuing pages that the plaintiff was vindicated after all, or that the defense lawyer ultimately was sanctioned for his conduct, or that courts or legislatures are enacting

12. See, e.g., NADER \& SMITH, supra note 1, at 88-89, 147-48, 206 (recounting General Motors' attempts to cover up the design defect inherent in the Corvair direct air heating system as well as its lack of stability on the road).

13. Ralph Nader's book UNSAFE AT ANY SPEED, featuring the Chevrolet Corvair, appeared in 1965. See NADER, UNSAFE AT ANY SPEED, supra note 2.

i4 NADER \& SMITH, supra note 1, at 70-72 (noting the significant number of deaths and injuries resulting from the Pinto, and the Ford Co.'s belated recall of the cars).

is. Id. at 74.

16. Id, at xxvii. 
rules or statutes in an attempt to eradicate the abusive tactic described. In fact, just about every episode the book recounts ultimately does have a favorable outcome. At most, then, what Nader and Smith describe are imperfections-often serious imperfections, but not complete failures of the civil justice system.

Thus, for example, Charles Keating did defraud many Lincoln Savings depositors by convincing them to divert their dollars into bonds issued by the parent American Continental Corporation (ACC), which later collapsed. However, Charles Keating did several years in a federal penitentiary, ${ }^{17}$ and the law firms that represented ACC and Lincoln, Kaye Scholer and Jones, Day, paid gargantuan fines. ${ }^{18}$

The book chronicles abuses in sealing court files after a corporation has lost an important case, in confidentiality agreements extracted as part of the settlement process to forestall information sharing by plaintiffs' attorneys, and in vacatur of judgments in return for immediate payment, thus robbing adjudicated proceedings of precedential effect. ${ }^{19}$ Late in the chapter, after Nader and Smith have gotten the reader agitated about these practices, they reveal that the Texas Supreme Court has enacted a rule requiring most court files to remain unsealed. ${ }^{20}$ Similarly, Idaho, Georgia, Michigan and Delaware have open file court rules. ${ }^{21}$ Indeed, recent years have witnessed several state initiatives aimed at preventing secrecy in court files. For example, Florida enacted a "Sunshine in Litigation Act" in 1990, Washington adopted substantially similar legislation in 1993, titled "The Public Right to Know Bill," and Louisiana followed Florida and Washington in 1995..$^{22}$ Finally,

17. See Adam Zagorin, Charles Keating, Demon of the $\$ 500$ Billion $S$ \& L Fiasco, Is Now Innocent, Sort Of, TMME, Feb. 3, 1997, at 36 (detailing the overtuming of Keating's wire and securities fraud conviction after he had served $4 \frac{1}{2}$ years of a 12 year sentence); Conviction Out in Keating Trial, NewsDAY, Dec. 3, 1996, at A16.

is Kaye Scholer paid a $\$ 41$ million fine, although the Office of Thrift Supervision sought $\$ 275$ million, and a further $\$ 63$ million in settlement of private suits, and Jones, Day paid a $\$ 51$ million fine. See, e.g., Harris Weinstein, Attorney Liability in the Savings and Loan Crisis, 1993 U. ILL. L. REv. 53; David B. Wilkins, Making Context Count: Regulating Lawyers After Kaye Scholer, 66 S. CAL. L. REv. 1145, 1214 n.279 (1993).

19. See, e.g., NADER \& SMITH, supra note 1, at 61 ("[A] parent may buy a child car safety seat unaware that other children have been severely injured or killed in that model. . . . A secret settlement may have swept the potential danger under the rug."); id. at 66 ("[S]ecrecy orders delay justice, increase the costs of litigation, and create a cynical 'catch me if you can' system of discovery.").

2a. See id. at 95.

21. See id. at 96.

22 See id. at 96-97. 
some local courts around the country have acted similarly. ${ }^{23}$

Judges have done likewise. When the government of the Philippines sued Westinghouse for allegedly having bribed Ferdinand Marcos to obtain favorable nuclear power contracts, Federal District Judge Dickinson Debevoise refused to seal the court file. ${ }^{24}$ The United States Court of Appeals for the Third Circuit affirmed. ${ }^{25}$ Sitting in Birmingham, Alabama, Federal District Judge Sam C. Pointer, Jr. signed an order prohibiting confidentiality clauses in agreements settling breast implant cases. ${ }^{26}$

In a chapter dealing with the intimidating, bullying SLAPP tactic, ${ }^{27}$ the authors explain how SLAPPed farmers who were sued for opposing an agribusiness corporation over a water rights measure ultimately were paid $\$ 15$ million in actual and punitive damages. ${ }^{28}$ An attorney who took on Shell Oil over resins used in plastic pipes got SLAPPed, but SLAPPed back with a lawsuit of his own, recovering $\$ 7.6$ million from Shell. ${ }^{29}$ Nine states have enacted anti-SLAPP statutes, ${ }^{30}$ and two Denver University law professors, Rock Pring and Penelope Canan, have promulgated a model statute for adoption by other states. ${ }^{31}$ There always will be bullies, in litigation and in the society at large just as much as on the playground. But together judges and legislators have recognized the chilling effect of the SLAPP suit and are doing something about it.

A later passage alarms the reader with sections entitled "Crush-

23. See id. (mentioning the Superior Court in San Diego County, California).

24 See Republic of the Philippines v. Westinghouse Elec. Corp., 139 F.R.D. 50 (D.N.J. 1991).

2s. See Republic of the Philippines v. Westinghouse Elec. Corp., 949 F.2d 653 (3d Cir. 1991).

26. See In re Silicone Gel Breast Implant Products Liability Litigation, No. CV 92-P10000-S, CIV.A.CV94-P-11558-S, MDL 926, 1994 WL 114580 (N.D. Ala. Apr. 1, 1994) (approving mentor class); In re Silicone Gel Breast Implant Products Liability Litigation, No. CV 93-P-11433-S, CV 92-P-10000-S, 1993 WL 795477 (N.D. Ala. June 2, 1993) (ruling on notice and other matters).

27. See NADER \& SMITH, supra note 1, at 158-92 (“SLAPP: Taking Care of Business").

28. See id. at 171

29. See Leonardini v. Shell Oil Co., 216 Cal. App. 3d 547 (3d Dist. 1989), cert. denied, 98 U.S. 919 (1990).

3a. NADER \& SMIT, supra note 1, at 180 (listing Califomia, Delaware, Massachusetts, Minnesota, Nebraska, Nevada, New York, Rhode Island, and Washington).

31. See George W. Pring \& Penelope Canan, SLAPPS: GeTTING SUEd FOR SPEAKnNG Our 201-07 (1996) (suggesting a "Model Anti-SLAPP Bill," which would be cited as the "Citizen Participation in Government Act of 199_"). 
ing the Ethical Whistle-Blowers, ${ }^{132}$ followed by another alarming section entitled "Harassing the Whistle Blowers." ${ }^{\text {"33 }}$ Only on the chapter's last page do Nader and Smith tell the reader that thirty five states have now enacted legislation to protect whistle blowers against the practices they earlier described. ${ }^{34}$

As with the insertion of "filler" material in the book, with their excessive alarmism, Nader and Smith rob their work of credibility. Citizens, plaintiffs mainly, do suffer anguish and anxiety because of the abusive litigation tactics Nader and Smith describe, but quite frequently those citizens achieve ultimate vindication. The civil justice system is not, then, as one-sided as Nader and Smith would have us believe.

\section{DEMONIZING CORPORATIONS AND INDIVIDUALS}

Among others, populists of the $1880 \mathrm{~s}$ and $1890 \mathrm{~s}^{35}$ and demagogues through the ages (Huey Long, for example) ${ }^{36}$ have rallied citizens to their cause by demonizing large corporations. Demonizing corporations has been a favorite Nader theme for decades, harking back to his 1970 s campaign for federal chartering of large publicly held corporations. ${ }^{37}$ Nader and Smith return to that theme in this volume. They bemoan:

The big-business imperative, driven by the petrochemical, automobile, oil, steel, tobacco, drug, insurance, banking, real estate, agribusiness, genetic-engineering, telecommunications, nuclear, foodprocessing, and other industries. . . . Corporations have spent a great deal of time, effort, and money establishing privileges and immunities, through their

\footnotetext{
32 See NADER \& SMTTH, supra note 1, at 218-22.

33. See id. at 222-31.

36 See id. at 231.

35. The populists had "seared into their memory images that would last a generation, images of the arrogant power of giant corporations backed by the military might of the state. . . " ROBERT C. MCMATH, JR., AMERICAN POPULISM: A SOCIAL HISTORY, 18771898, at 4 (1993).

36. In his Louisiana gubernatorial campaigns, Huey Long built for himself the image of "the man who knew how to handle the big corporations"; in every speech attacked "the New Orleans press and the corporations"; and in particular demonized the Standard Oil Company as "an arrogant corporate power" favoring "the Crescent [by imports of Turkish oil] over the children of Moses."' T. HARRY WILIAMS, HUEY LONG 180, 203-04 (1969).

37. See Ralph Nader et al., Constitutionaltzing the CORPoration: The CASE FOR General Chartering of Giant Corporations (1976); NADAR ET al., TAMmig the GIANT CORPORATION, supra note 2.
} 
attorneys, that real people do not possess, thus creating uneven playing fields that allow corporations to maneuver and dominate in a way that individuals never could. ${ }^{38}$

In this book, Nader and Smith add a new dimension: they demonize individuals as well. Washington, D.C. super lawyer Lloyd Cutler is "a genius, but an evil genius." 39 Late in the book, ${ }^{40}$ ten pages lambast the special prosecutor who would be dean, ${ }^{41}$ Kenneth Starr. Nader and Smith criticize Starr for whom he represents, including General Motors in the side-saddle pickup truck fuel tank litigation ${ }^{42}$ and well-known corporate bandit Victor Posner, against whom the Second Circuit affirmed a lifetime ban on involvement in the affairs of a publicly held corporation. ${ }^{43}$ They excoriate Starr further for refusing to take a leave of absence from super law firm Kirkland and Ellis, continuing to represent clients while acting as special prosecutor even though all predecessors in that office have resigned from or taken a leave from their permanent employment positions. ${ }^{44}$

Many corporations and some individuals demonized by Nader and Smith do, indeed, deserve to be demonized. The difficulty, however, is the prescription to which demonization inevitably leads.

\section{PRESCRIPTIONS FOR THE CIVIL JUSTICE SYSTEM}

For all its filler material, half-truth and excessive alarmism, No Contest is a good read. I read it almost non-stop, on two airplane flights and in one long airport layover. There are ills in the civil

38. NADER \& SMITH, supra note 1 , at $\mathrm{xvi}$-xvili.

39. Id. at 13 .

4. See id. at $320-29$.

41. Compare Charles Zehren, Kenneth Starr to Take Academic Post, NEWSDAY, Feb. 18, 1997, at A4 (reporting that Starr was to become dean of Pepperdine University Law School and director of the newly founded Public Policy Institute), with James Toedtman, Starr's Back: He Rejoins Whitewater Probe, NEwSDAY, Feb. 22, 1997, at A3 (reporting the withdrawal of the announcement that Starr would join the Pepperdine faculty on August 1, 1997).

2. See NADER \& SMTTH, supra note 1 , at 323.

a. In Posner v. SEC, 16 F.3d 520, 522 (2d Cir. 1994), cert. denied, 513 U.S. 1077 (1995), the court upheld "eternal boardroom banishment" for corporate looter Posner and his son. While special prosecutor, Starr also represented Posner in his petition for a writ of certiorari to the Second Circuit. See NADER \& SMITH, supra note 1, at 324.

4 See NADER \& SMITH, supra note 1, at 327 (stating that Starr's "indifference to [his] multiconflicting status and its ethical ramifications-while being hailed as a person of integrity and a key counselor to leading corporations-threatened to further erode already crumbling standards of propriety for the profession"). 
justice system. ${ }^{45}$ Many of them are attributable to the "winning justifies everything" attitude prevalent among attorneys. Many attorneys engage in abuse of the system while representing resourcerich large corporations against individuals and smaller law firms. Lastly, many of those attorneys seem to be of the pin-striped variety that populate the confederacy of three or four large law firms that dominate most American cities. City by city these confederacies have come to have a corner on representation of large publicly held corporations. ${ }^{45}$

The difficulty with demonization of those and the corporations they represent is that development of the subject in that manner leads to calls for punishment, retribution, and increased regulation. That is where Nader and Smith take us. Law firms should be punished for the litigation tactics of their members: "To do less is to permit law firm managers to countenance the ethical indifference, if not outright ethical and criminal violations, occurring in the practice of corporate law today. ${ }^{, 47}$

Too much punishment, however, is antithetical to the aims of the civil justice system. The civil justice system removes disputes from the level of the streets to a more rarefied intellectual plane.

4. Those ills persist despite the commands of the Civil Justice Reform Act of 1990 for the federal courts. 28 U.S.C. $\S \S 471-482$ (1994) (codified as Chapter 23: "Civil Justice Expense and Delay Reduction Plans"). That act, inter alia, commanded each United States district court, "in consultation with an advisory group," to consider "principles and guidelines of litigation management and cost and delay reduction. . . II. § 473(a). This "bottom up," or grass roots, reform effort was to consider the following factors in complex cases: "early and ongoing [court] control of the pretrial process"; means to encourage "cost-effect discovery through voluntary exchange of information"; and "careful and deliberate monitoring through a discovery-case management conference or a series of such conferences." Id. § 473(a)(1)-(4).

46. At times the confederacy of large law firms is regional or national in scope. For example, see. Ashland Oil, Inc.'s use of the large Pittsburgh firm of Kirkpatrick and Lockhart to conduct an "independent" investigation of thinly disguised bribes Ashland paid to obtain foreign oil. See NADER \& SMITH, supra note 1, at 52-59. An inter-city confederacy of large law firms then came to Kirkpatrick's aid; power lawyers from Fried, Frank, Harris, Shriver \& Jacobson and from Arnold \& Porter testified that the Kirkpatrick report had been prepared with "professionalism and independence," id. at 55, even though jurors remained unconvinced, one stating that the Kirkpatrick partner who testified was "[a]bsolutely a liar." Id. at 57.

47. Id. at 355 (arguing that disciplining a law firm for its individual lawyers' misconduct will encourage firms to supervise the way its members handle cases). Indeed, that is a remedy put in place several years before Nader and Smith wrote. In 1993, Congress amended Rule 11(c) of the Federal Rules of Civil Procedure to permit sanctions against law firms as well as against individual attomeys, reversing Pavelic \& Leflore $v$. Marvel Entertainment Group, 493 U.S. 120 (1989). See FED. R. CIV. P. 11(c). 
In the latter sphere, attorneys and courts supposedly substitute reasoned discourse and argument for self-help, fisticuffs and ad hominem attack. What Federal Rule of Civil Procedure 11, providing for sanctioning (punishing) lawyers for frivolous court papers or arguments, has shown us, however, is that too much opportunity for punishing one's lawyer opponent has brought matters full circle. Lawyers now attack opposing lawyers rather than progressing steadily toward solution of the underlying dispute between the parties. In that manner, on a slightly different level, all of the unseemly ad hominem attack the civil justice system seeks to avoid has been reintroduced with a vengeance.

\section{Structural Change Rather Than Regulation AND PUNISHMENT AS A PRESCRIPTION}

As Nader and Smith point out, ${ }^{48}$ state and federal judges have to be more proactive. They must recognize naked and thinly veiled SLAPP lawsuits for what they are, dismissing them at the earliest opportunity. In certain categories of cases, judges must reverse course, toward less rather than more due process, giving short shrift to "Crush-em, Bash-em and Sanction-em" type Rule 11 motions or SLAPP lawsuits.

In the area of discovery abuse, Professor Charles Yablon has recently written that perhaps the "best solution for lawyer misconduct in discovery proceedings is the same one parents use when their kids act up on long car trips-tell them to 'shut up and knock it off,' preferably in a really loud voice." ${ }^{39} \mathrm{He}$ elaborates:

One problem with current law is that many judges are reluctant to pull out the big strap of discovery sanctions except when convinced that the lawyers involved are so utterly recalcitrant that they deserve a serious whupping. This piece suggests that a major improvement in the moral education of litigators would be effected by increased sanctioning of smaller, more annoying discovery abuses with smaller, more annoying punishments. ${ }^{50}$

4. See NADER \& SMTTH, supra note 1, at 128-29 (stating that judges "must get tough" in cases of discovery abuse); see also id. at 181 ("[J]udges will continue to play a key role in preventing SLAPPs.").

4. Charles Yablon, Stupid Lawyer Tricks: An Essay on Discovery Abuse, 96 CoLum. L. REV. 1618, 1619 (1996).

sa. Id. at 1620 . 
Proactive judicial attitudes go further toward curing the ills of the civil justice system than other reforms proposed. For example, means of alternative dispute resolution-mediation, mini-trial, renta-judge ${ }^{51}$ - have merely become additional obligatory steps on the route to the courthouse. They represent yet another opportunity for the lawyers Nader and Smith criticize to bill more hours in preparing and then attending the mediation. ${ }^{52}$ By contrast, proactive panels of judges who accept no nonsense and move all civil cases to trial in one year or less may cause more cases to settle than all the meditations and arbitrations in their district put together.

But what about structural change? As has been seen, increased opportunity for punishing one's opponent has theoretical drawbacks. Judges can be only so proactive, duty bound as they are to mete out due process to all litigants and under the glare of the public eye, in the form of journalists such as Nader and Smith, or their opposite numbers, if they act too peremptorily.

\section{The Federal Rules Of Civil Procedure as an EXPERIMENT THAT HAS FAILED}

We need trials. ${ }^{53}$ Some public business must see the full light of day. We do bargain in the shadow of the law, ${ }^{54}$ so we need trials and appeals to produce law in whose shadow we can bargain.

But perhaps much of the root cause, pointing to a possible

51. See The Civil Justice Reform Act of 1990, 28 U.S.C. § 473(a)(6)(B) (1994) (commanding each United States district court to consider local rules that would refer "appropriate cases to alternative dispute resolution programs that ... the court may make available, including mediation, minitrial, and summary jury trial"). Experienced trial lawyers, however, know that the best alternative dispute resolution mechanism is the certain prospect of a trial in the near future.

${ }^{52}$ Large law firms' billing practices are described as the "BUTS" principle in NADER \& SMITH, supra note 1, at 232-55. "BUTS" stands for "Bill Until They Squawk." Id. at 233.

53. For that reason, there has been a backlash to the headlong rush toward alternative dispute resolution. See, e.g., Owen M. Fiss, Against Settlement, 93 YALE L.J. $10^{\circ} 3$ (1984).

se Professors Robert Mnookin and Lewis Komhauser pointed this out in their seminal piece Bargaining in the Shadow of the Law: The Case of Divorce, in which they discussed the private negotiations and bargaining that occurs outside of the courtroom in divorce proceedings. See Robert Mnookin \& Lewis Kornhauser, Bargaining in the Shadow of the Law: The Case of Divorce, 88 YALE L.J. 950 (1979); see also Robert Cooter et al., Bargaining in the Shadow of the Law: A Testable Model of Strategic Behavior, $11 \mathrm{~J}$. LEGAL STUD. 225 (1982) (providing a mathematical analysis of the effectiveness of pretrial bargaining). 
structural solution, is the way we get there, that is, to a trial. The Federal Rules of Civil Procedure have created a system whereby litigants no longer move in linear fashion toward the resolution of the dispute between them. Instead, we have a system that has created an opportunity for numerous "trials within trials." In turn, that system favors the litigant who has the resources and can stay the course which often happens to be the large corporation and the sizeable law firm that represents it.

In litigation today we can have numerous motions, each with supporting briefs, opposition briefs, and reply briefs, or with cross motions, two of each kind of brief, that do little or nothing toward moving the underlying dispute toward trial. ${ }^{56}$ Thus, major battles can be fought over motions to disqualify counsel, numerous motions and cross motions for sanctions, motions to compel discovery, motions to seal the file, motions to certify the class, repeated motions to decertify the class, or to decertify subclasses, motions as to the demand required in derivative litigation, and so on. Some perceptive judges have observed this tendency to create litigation within litigation. ${ }^{57}$

53. As subtext, a related effort by the anti-plaintiff forces may be to create specialized codes of civil procedure within civil procedure. They recently did so with the Securities Litigation Reform Act of 1995, 15 U.S.C. $\$ 77 \mathrm{z}-1$ (Supp. I 1995), the thrust of which is to create opportunities for "trials within trials" as, for example, in creation of ancillary proceedings to determine the "most appropriate plaintiff" in securities class actions and to conduct mandatory Rule 11 reviews of plaintiffs' pleadings. See generally Douglas M. Branson, Running the Gauntlet: A Description of the Arduous, and Now Ofien Fatal, Journey for Plaintiffs in Federal Securities Law Actions, 65 U. CIN. L. REV. 3, 32-35 (1996); Douglas M. Branson, Chasing the Rogue Professional After the Private Securities Litigation Reform Act of 1995, 50 SMU L. Rev. 91, 114-15 (1996) (explaining the complex and expensive procedures for providing notice to the "most appropriate plaintiff" ("MAP") in class litigation). We may expect to see future "reform" efforts to enact procedural "add-ons" applicable to certain categories of cases.

36. I have had counsel opine to me that not to file a cross motion, and have six briefs rather than three, in their opinion may be malpractice.

57. For example, see the comments of Judge Frank Easterbrook: "[T]he demand rule [in shareholder derivative suits] creates more litigation than it prevents. . . . It is easy to point to hundreds of cases, including this one, in which the demand requirement was itself the center-piece of the litigation. An approach uncertain in scope and discretionary in operation . . . promotes litigation." Kamen v. Kemper Fin. Servs., Inc., 908 F.2d 1338, 1342 (7th Cir. 1990), rev'd, 500 U.S. 90 (1991). See also the comments of Delaware Chancellor Brown commenting on the Special Litigation Committee procedure in shareholder suits:

[The procedure] has the pragmatic effect of setting up a form of litigation within litigation. (At this point in this case, we are some three years after the amended complaint was filed, we have had three full-scale, briefed arguments, we have had all of the investigation .... and as yet we have not reached the 
Even with dispositive motions (motions to dismiss, for judgment on the pleadings, or for summary judgment), which do move the dispute toward resolution, large law firms adopt what I term the "salami" strategy. Rather than one or two motions, large law firms slice up their arguments into numerous motions for partial summary judgment. As to each, the weaker opponent has to gather evidence, prepare counter affidavits, research and write an opposition brief, and perhaps prepare and deliver an oral argument.

I know that my thesis will be regarded as heresy and that Judge Charles Clark, the father of the Federal Rules, ${ }^{58}$ would be rolling in his grave were he to hear these sentiments, but I offer one additional piece of evidence, albeit anecdotal.

In recent years, my consulting on corporate and securities law matters has carried me into law firm offices and courts in New York, Illinois, Alabama, Idaho, Alaska, Washington, Oregon and Hawaii. The highest level of professionalism and the greatest amount of civility I see among lawyers is in Oregon. And, guess what? Of all those jurisdictions, Oregon is only one that has not adopted the Federal Rules of Civil Procedure. ${ }^{59}$

Of course, the cause may be the laid-back lifestyle and good health of Oregonians, the sylvan setting, the mild climate, the good food and wine, and the frequent vision of snow capped mountains in the Cascade range. I also suspect, though, that Oregon rules of civil procedure permit fewer opportunities to engage in "litigation within litigation." I certainly know that to be true with respect to discovery.

In Oregon, opposing sides do not have to disclose who their witnesses may be. To a degree, litigation is as of old, "litigation by ambush," or the "sporting theory of justice," as Dean Roscoe Pound termed it. ${ }^{60}$ Opposing counsel does not know who the op-

point of any of the normal discovery and motion practice permitted by the Court Rules).

Kaplan v. Wyatt, 484 A.2d 501, 511 (Del. Ch. 1984), aff d, 499 A.2d 1184 (Del. 1985).

s\& See, e.g., 4 Chardes ALAN Wright \& ARTHUR Miller, Federal Practice AND PROCEDURE § 1004 (1987) (explaining that Judge Charles Clark, while Dean of Yale Law School, was appointed as Reporter for the Advisory Committee that authored the Federal Rules of Civil Procedure, 1935-38).

39. See MARTINDAle-HUBbell LAW Digests (1996) (State by State Compilation, March 14, 1997, on file with author); see also Douglas M. Branson, The American Law Institute Principles of Corporate Governance and the Derivative Action: A View from the Other Side, 43 WASH. \& LEE L. REV. 399, 402 n.14 (1986) (comparing derivative litigation in Portland, Oregon or Portland, Maine with derivative litigation in Delaware or under the American Law Institute proposals).

6. Roscoe Pound, The Causes of Popular Dissatisfaction with the Administration of 
posing side's expert is until the expert begins testimony. Upon completion of direct examination, opposing counsel receives the materials the expert reviewed with a long recess or lunch break to prepare cross examination. In many ways, it is a more efficient system. The cross examination is just as sharp and thorough as in other jurisdictions. A side effect is much more civility among members of the bar. The animosities that build up through protracted discovery, with motions to compel, argument over scheduling depositions, motions for sanctions, trails within trials, and the like seem less extreme, or non-existent, in Oregon. ${ }^{61}$

\section{CONCLUSION}

I recommend Nader and Smith's No Contest. Those who read this book will be perceptive enough to discount heavily the rhetoric, the re-cycled material, and the excessive alarmism.

As a prescription for what ails the civil justice system, however, I believe that thought has to go beyond demonization of corporations and their lawyers and calls for additional regulation and punishment. My own prescription is to reexamine the federal rules with a view toward minimizing opportunities the rules create for "litigation within litigation," cross motions, "salami" tactics and other stratagems that favor the stronger party. The goal of civil justice reform must be to create a system in which the maximum amount of resources possible are directed toward moving litigants' disputes towards settlement or trial, and in which the opportunities to create "sideshows" and "trials within trials" are minimized, if not eliminated. Somehow I believe that Ralph Nader and Wesley J. Smith would agree with me.

Justice, 29 A.B.A. REP. 395 (1906).

6. Cf. Abraham D. Sofaer, Sanctioning Attorneys of Discovery Abuse Under the New Federal Rules: On the Limited Utility of Punishment, 57 ST. JOHN's L. REv. 680, 696-97 (1983) (illustrating that as the number of discovery requests in a case rises to a high level, the number of discovery disputes doubles, while in cases with little discovery, disputes are nearly non-existent). 
$$
\text { . }
$$ 